\title{
David's Initial Philistine Victories According to Josephus
}

\section{ABSTRACT}

C T Begg

Catholic University of America

\section{David's Initial Philistine Victories According to Josephus}

The Bible twice relates, in Samuel 5:17-25/1 Chronicles 14:8-17, David's initial pair of victories over the Philistines. This essay focuses on a third version of David's triumphs, $i$ e that of Josephus in his Ant 7.70-77, comprising this in detail with its two Biblical parallels (as represented by MT, Codex Vaticanus and the Lucianic/Antiochene MSS of the LXX, the Targums, and the Vulgate). The comparison seeks to find answers to such questions as: did Josephus use both Biblical accounts in composing his version or did he rather limit himself to one of these to the exclusion of the other? Which text-form(s) of 2 Samuel 5:17-25 and/or 1 Chronicles 14:8-17 did he have available? What sort of rewriting techniques are evidenced by his version? Are there features to that version which notably distinguish it from the Biblical accounts? Why did Josephus include the two battle episodes in his work at all, and what message might he have intended his version of these happenings to convey to Ant's double audience, $i e$ cultivated Gentiles and fellow Jews?

2 Samuel 5:17-25 relates, as a sequel to David's capture of Jerusalem (5:610), the king's repulse of two successive incursions by the Philistines'. The latter episodes are reproduced, in 1 Chronicle 14,8-17, by the Chronicler, who, however, situates them within the three-month interlude between David's first, abortive attempt at moving the ark (1 Chronicles 13) and his later, successful attempt at doing so (1 Chronicles 15-16)2. In this essay, I propose to focus on yet another retelling of David's Philistine triumphs, i e that by Josephus in his Antiquitates Judaicae (hereafter Ant) 7.71-77)3. I shall proceed in this endeavor by making a detailed comparison between Josephus' version and its Biblical parallels as represented by the following major witnesses: MT (BHS) ${ }^{4}$, Codex Vaticanus (hereafter B) ${ }^{5}$ and the Lucianic (hereafter L) or Antiochene MSS ${ }^{6}$ of the LXX, the Vulgate (hereafter Vulg)7, Targum Jonathan of the Former Prophets (hereafter TJ)8 and the Targum on Chronicles (hereafter TC) ${ }^{9}$. I undertake this investigation with a variety of questions in view. In retelling David's initial successes against the Philistines, did Josephus draw on both Biblical sources, 
or did he use one to the exclusion of the other? Which text-form(s) of Samuel and/or Chronicles were employed by him in composing Ant 7.7177? What sort of rewriting techniques did he apply to the data of his source(s)? Are there noteworthy distinctive features to Josephus' version which result from his application of these? Why did he choose to incorporate the episodes in question into his selective recapitulation of Biblical history? Finally, what messages might his relecture be intended to convey to Ant's double audience, i e cultivated Gentiles and fellow Jews?

In turning now to my comparison, I divide up the material to be studied into two parallel segments: 1) First Battle (2 Sam 5:17-21/1 Chronicles 14:8-12/Ant 7.71-74); and 2) Second Battle (5:22-25/14:1317/7.75-77).

\section{FIRST BATTLE}

The Biblical sources commence their opening battle account with a double indication concerning the movements of the Philistines (5:17a,18// $14: 8 a, 9)$, between which stands a notice on David's counter-move $(5: 17 b / /$ $14: 8 b)$. Josephus leaves aside the latter item ${ }^{10}$. His doing this allows him (7.71) to work together into a continuous sequence the sources' separated

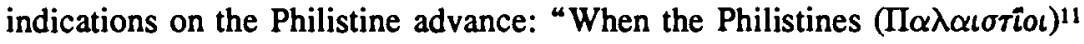
learned that David had been chosen king (B $\alpha \sigma i \lambda \varepsilon \alpha \ldots \dot{\alpha} \pi \circ \delta \varepsilon \delta \varepsilon \imath \gamma \mu \varepsilon \dot{\nu} \nu \nu)^{12}$ by

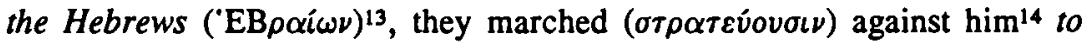
Jerusalem ${ }^{15}$ and when they had taken the so-called Valley of the Giants $\left(\tau \dot{\eta} \nu \kappa o \iota \lambda \alpha \dot{\alpha} \alpha \tau \hat{\omega} \nu \Gamma(\gamma \alpha \dot{\alpha} \nu \omega \nu)^{16},-\right.$ this is a place not far from the city ${ }^{17}$,- they encamped ( $\sigma \tau \rho \alpha \tau \sigma \pi \varepsilon \delta \varepsilon \dot{0} \sigma \nu \tau \alpha))^{18}$ there"19.

2 Samuel 5:19a $/ 1$ Chronicle 14:10a $\alpha$ relate a further measure (cf $5: 17 \mathrm{~b} / 14: 8 \mathrm{~b}$ ) taken by David in face of the Philistine threat, $\mathrm{i} e$ his "inquiring of the Lord/God", the modality of which they leave indeterminate. Josephus (7.72) renders the manner of the "inquiry"David's first and only reaction to the Philistines' moves in his presentation

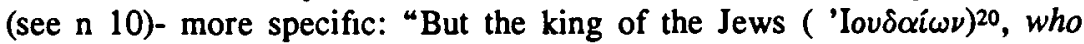
permitted himself to do nothing without an oracle ( $\pi \rho \circ \phi \dot{\eta} \tau \varepsilon \iota \alpha \varsigma)$ and a com-

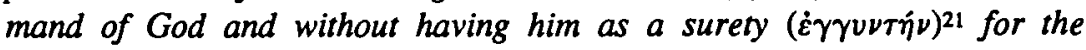

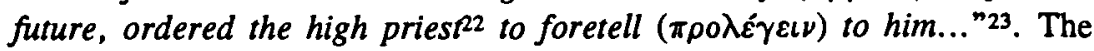
sources $(5: 19 \mathrm{aB} \gamma / 14: 10 \mathrm{aB} \gamma)$ continue with a "quotation" of David's double, direct discourse question to the Deity: "Shall I go up against the Philistines? Wilt thou give them into my hand?" The historian's rendition recasts the king's words in indirect discourse ${ }^{24}$, while also focussing these

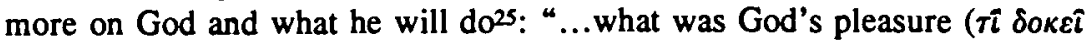


$\tau \hat{\varphi} \theta \varepsilon \hat{\varphi})^{26}$ and what the outcome of the battle ( $\tau \grave{o} \tau \varepsilon \lambda o \varsigma \tau \hat{\eta} \varsigma \mu \alpha \dot{\alpha} \chi \eta \varsigma$ ) would

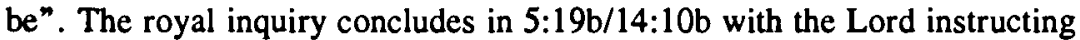
David "Go up, and I will give them into your hand". In line with his own previous account, Josephus (7.73a) has the divine reply mediated by the high priest, likewise transposing this into indirect discourse and making it a transition to what follows: "and when he (the high priest) prophesied

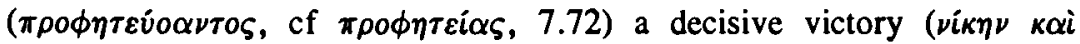
$\left.\kappa \rho \dot{\alpha} \tau O \varsigma)^{27}\right) \ldots " .$. The entire foregoing reworking of the sources' notice on David's "inquiry" exemplifies several wider tendencies of Josephus' version of Biblical history in $A n t, \mathrm{i}$ e interjection of the terms "prophet", "prophesy", "prophecy" in contexts where the Bible lacks such, and his recurrent association of the priesthood with prophetic activity ${ }^{28}$.

The sources (5:20a/14:11a) recount the actual battle in quite summary terms: David goes up to "Baal-perazim" (MT) where he defeats the Philistines. Josephus embellishes notably, even while leaving aside the name of the battle-site: "(David) led his force out ( $\dot{\varepsilon} \xi \dot{\alpha} \gamma \varepsilon \iota)^{29}$ against the

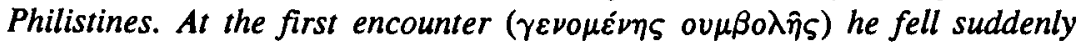
upon the enemy's rear ${ }^{30}$, slew ( $\dot{\alpha} \pi \varepsilon \dot{\varepsilon} \tau \varepsilon(\nu \varepsilon)$ part of them and put the rest to flight" ${ }^{31}$. To their mention of "Baal-perazim" as the battle site the Biblical narratives attach an aitiological remark $(5: 20 \mathrm{~b} / 14: 1 \mathrm{lb})$, connecting that name with a statement by David on the occasion of his victory ${ }^{32}$. Having left aside the site name itself (see above), Josephus likewise dispenses with the Bible's etymological elaboration of this ${ }^{33}$. Conversely, he fills the "lacuna" thus created by him with an extended editorial comment (7.74) whose purpose is to preclude readers from viewing David's just-won victory as a mere "pushover" ${ }^{34}$. This reads:

Let no one, however, suppose that it was a small army of Philistines that came against the Hebrews (see 7.71), or infer from the swiftness of their defeat ${ }^{35}$ or from their (i e the Philistines') failure to perform any courageous or noteworthy $\left(\gamma \varepsilon \nu \nu \alpha \hat{\imath} o \nu \mu \eta \delta \grave{\varepsilon} \mu \alpha \rho \tau \nu \rho i \alpha \varsigma \grave{\alpha} \varsigma\llcorner o \nu)^{36}\right.$ act that there was any reluctance $(B \rho \alpha \delta v \tau \hat{\eta} \tau \alpha)^{37}$ or cowardice $(\dot{\alpha} \gamma \varepsilon \dot{\varepsilon} \nu \varepsilon \iota \alpha \nu)^{38}$; on the contrary it should be known that all Syria and Phoenicia and beside them many other warlike ( $\pi 0 \lambda \lambda \dot{\alpha} \kappa \alpha i$ $\mu \alpha \alpha(\mu \alpha)^{39}$ nations fought along with them and took part in the war ${ }^{40}$.

The sources round off $(5: 21 / 14: 12)$ their first battle account with a notice of David's disposition of the idols/gods left behind by the routed Philistines. Josephus reserves this item for the close of his second battle story (see on 7.77 below) ${ }^{41}$. In place thereof he proceeds $(7.75)$ directly to 
his (greatly amplified) version of the Biblical introductions (5:22/14:13) to the Philistines' new military initiative:

It was for this reason alone [i e their de facto courage and eagerness for combat as spoken of in 7.74] that, after having been defeated so

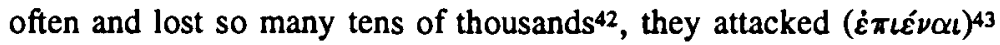
the Hebrews (see 7.71,74) with a larger force. In fact, after their discomfiture in these battles $(\mu \alpha \dot{x} x \alpha \iota)^{44}$ they came against David with an army three times as large 45 , and encamped

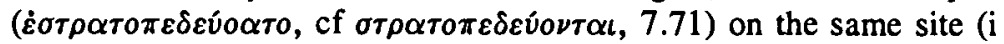
e the "Valley of the Giants", 7.71) ${ }^{46}$.

David, according to 5:23/14:14, reacts to the renewed Philistine aggression by again "inquiring of the Lord/God" (compare 5:19/14:9). Josephus' rendition (7.76a) of the royal initiative at this juncture echoes the wording employed by him for David's previous "inquiry" (see 7.72): "Again the Israelites' king (compare "king of the Jews", 7.72)47 inquired of God

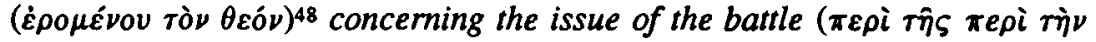
$\mu \alpha \chi \chi \eta \nu \dot{\varepsilon} \xi o \delta \delta o v)^{49}$, and the high priest gave the prophetic warning $(\pi \rho \circ \phi \eta \tau \varepsilon u ́ \varepsilon l)^{50} \ldots "$.

Following their mention David's "inquiry", 5:23a $\alpha / 14: 14 \mathrm{a} \alpha$, the sources go on, in 5:23aß-24/14:14aß-15, to quote the Deity's response: David is not to launch a frontal attack on the Philistines, but to await the divine signal that will be given him. The various witnesses all represent that signal as involving the "agitation" of some sort of "trees", but differ in their designation for the trees in question ${ }^{51}$. The Josephan version of the instructions given David clearly reflect the wording of BL 5:23-24 on the latter point as against those of the other witnesses: "(David is told) to hold

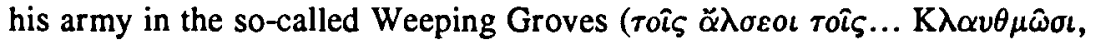
cf L 5:24 $\tau \hat{\omega} \nu \dot{\alpha} \lambda o \hat{\omega} \nu \tau o \hat{v} \kappa \lambda \alpha \nu \theta \mu \hat{\omega} \nu \circ \varsigma)$ not far from the enemy's camp

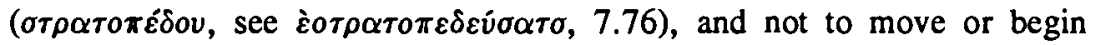

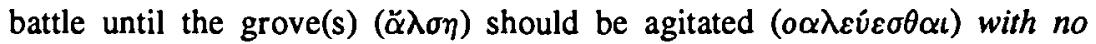

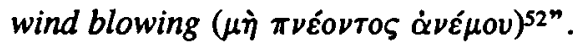

2 Samuel 5:25a/l Chronicles 14:16a dispose of the actual second combat episode in quite summary terms: "And David did as the Lord/God had commanded him". Just as he did with the initial battle (see 7.73), Josephus greatly elaborates (7.77a) on this jejune datum:

And when the grove was agitated and the moment came which God had foretold $(\pi \rho \circ \varepsilon \pi \varepsilon \nu)^{53}$ to him, he delayed no longer, but went out 
to seize the victory which he saw awaiting him ${ }^{54}$. The enemy's lines did not stand up under his attack but from the very first encounter $(\sigma \nu \mu \beta 0 \lambda \hat{\eta} \varsigma$, see 7.73$)$ were routed, with David close behind, slaughtering ( $\kappa \tau \varepsilon i \nu \omega \nu$, cf $\dot{\alpha} \pi \varepsilon \dot{\varepsilon} \tau \varepsilon \varepsilon \nu \varepsilon, 7.73$ ) them ${ }^{55}$.

The sources conclude their second battle account $(5: 25 \mathrm{~b} / 14: 16 \mathrm{~b})$ by noting David's (or the Israelites', so MT 14:16) "smiting" the Philistines from Geba (so MT 5:25)/ Gibeon (so BL 5:25/MT BL 14:16) to Gezer. The historian leaves aside the starting point of the pursuit, but otherwise elaborates $(7.77 \mathrm{~b})$ on this development as well: "He pursued $\left(\delta\llcorner\dot{\omega} \kappa \varepsilon \iota)^{56}\right.$ them as far as the city ( countrys8, and when he plundered $(\delta \iota \alpha \rho \pi \dot{\alpha} \zeta \varepsilon \iota)^{59}$ their camp

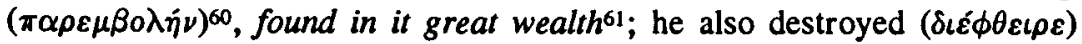

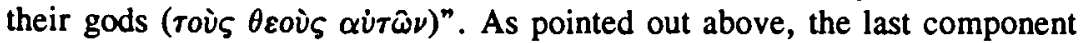
of the foregoing sequence, speaking of David's disposition of the Philistines' "gods", represents Josephus' "delayed" utilization of the notice which, in his sources (see 5:21/14:12), serves to conclude the first battle account ${ }^{62}$. More specifically, in representing David as "destroying" the Philistines' "gods" Josephus aligns himself with the wording of 14:12 (MT

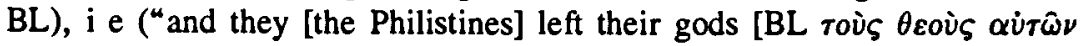
$=$ Josephus] there), and David gave command, and they were burnt" against MT (and B) 5:21 which has the Philistines leaving their "idols" (so

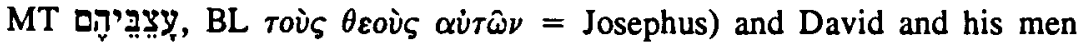
"taking" (B $\dot{\varepsilon} \lambda \dot{\alpha} \beta 0 o \alpha \nu)$ these ${ }^{63}$.

The Chronicler provides his foregoing double battle account (14:816) with a notice (14:17) highlighting the far-reaching effects of David's victories: "and the fame of David went out to all lands, and the Lord brought the fear of him upon all lands". Like Samuel, Josephus has no equivalent to this item ${ }^{64}$. Instead, again like Samuel, he proceeds directly (7.78) to a new episode, i e David's transfer of the ark to Jerusalem, 2 Samuel $6 / 1$ Chronicles 13-16/Ant 7.78-8965.

\section{CONCLUSION}

Now that I have completed my detailed comparison of Ant 7.71-77 with its Biblical parallels, I shall, by way of conclusion, briefly summarize my findings on the questions with which this essay began. The first of those questions concerned whether or not Josephus made use of both Biblical accounts of David's double victory. Our investigation yielded indications that he did, in fact, do so. Thus, his mention of the Philistine "camp" 
plundered by David (7.77) and his representation of David "destroying" the Philistine "gods" reflects the peculiar readings of 1 Chronicles 14:16b against those of 2 Samuel 5:25b (see nn. 60,63). On the other hand, his placing of our episode accords with that found in 2 Samuel 5-6, i e as an interlude between the account of events in Jerusalem (5:6-16/7.61-70) and the narrative of David's transfer of the ark there (6:1-23/7.78-89) contra the sequence of 1 Chronicles 11-16 (see nn. 10,65).

A related opening question had to do with the text-form(s) of 2 Samuel 5:17-25 and/or 1 Chronicles 14:8-17 utilized by Josephus. The evidence uncovered in this study points towards Josephus' use of a text of the two passages more like that of "LXX" (BL) than our "MT". Such evidence includes his name "Valley of the Giants" (7.71, so BL 14:9; compare MT 5:18/14:9 "Valley of Rephaim") for the site of the first battle, the designation "Weeping Groves" (7.76, so BL 5:23-24; compare MT 5:2324/14:14-15 "balsam trees", see n. 51) of the locale where David is to await the second Philistine advance, and his making David (7.77, so BL 14:16b) rather than the Israelites as a whole (so MT 14:16b) the one to plunder the Philistines' "camp" 66.

Our next initial question focussed on the rewriting techniques brought to bear by Josephus on the data of his sources in 7.71-77. Its brevity notwithstanding, this pericope of Ant was found to exemplify a whole range of such techniques, these being, as might be expected, intimately interconnected. For one thing, Josephus elaborates on various source items, e g, David's initial inquiry (7.72; compare 5:19/14:10), as well as both his first $(7.73$; compare $5: 20 \mathrm{a} / 14: 11 \mathrm{a})$ and second $(7.77 \mathrm{a}$; compare $5: 25 \mathrm{a} / 14: 16 \mathrm{a})$ rout of the Philistines, and the sequels to the latter event (7.77b; compare 5:25b/14:16b). He also, however, omits a number of Biblical particulars: David's initial response to the first Philistine advance $(7.71$; compare 5:17b/14:8b, see $n .10)$, the site ("Baal-perazim") of the first battle (7.73; compare 5:20a/14:11a, see $n$. 33), the related aitiology of the site-name $(5: 20 \mathrm{~b} / 14: 20 \mathrm{~b})^{67}$, God's announcement about his upcoming advance against the Philistines (7.76; compare 5:24b/14:15b, see n. 52), the starting point (Geba/Gibeon) of David's pursuit of the Philistines (7.77; compare 5:25b/14:16b), and the generalizing conclusion of 14:17 (see n. 64). Josephus likewise re-arranges the sequence of his sources, "anticipating" (7.73) the reference (2 Sam 5:23) to David's coming upon the Philistines "from the rear" (see n. 30), while "delaying" that concerning his disposition of the Philistine "gods" (7.77b; compare $5: 21 / 14: 12$, see n. 62). Lastly, the historian freely modifies/replaces elements of the Biblical presentations. Thus, stylistically, he recasts direct as 
indirect discourse (see 7.72-73; compare 5:19/14:10 and 7.76; compare 5:23-24/14:14-15), and introduces no less than seven historic present forms (see $7.71,73,75,76,77$ ) into his version. This feature also, however, extends to the content of the Biblical narratives: in his retelling both of David's inquiries of God are conducted via a prophet rather than directly (see 7.72-73a; compare 5:19/14:11 and 7.76; compare 5:23-24/14:14-15), just as the aitiology of the name "Baal-perazim (5:20b/14:11b) gives way to an extended commentary on the character of David's initial victory and the Philstines' second attack (7.74-75, see n. 67).

Among my opening questions there also figured one concerning the distinctiveness of Josephus' account of David's double victory vis-à-vis its Biblical parallels. Here, I recall the following distinctive features of Josephus' version (and, indeed, of Ant overall). Throughout, the historian accentuates the magnitude of the Philistine threat (see especially the long, interjected comment on the matter in 7.74-75), as also the piety, energy, and efficacy with which David responds thereto (see nn. 23, 31, 34, 42, 44). He highlights too the prophetic-priestly character of the entire affair (see nn. 28, 50), while somewhat downplaying God's direct involvement in the Philistines' definitive rout (see n. 52).

My two final opening questions asked about Josephus' reason for including the material of 5:17-25/14:8-17 in his history and the messages his version might be intended to convey to his double audience, $\mathrm{i} e$ cultivated Gentiles and fellow Jews ${ }^{68}$. In responding now to that two-fold query, I suggest that Josephus opted to include the material - suitably reworked by him - because he recognized its usefulness in furthering his own purposes with regard to both his projected readerships. In particular, the story of David's double triumph over the Philistine hosts would help make clear to Gentile readers the falsity of contemporary canards about the Jews' failure to produce figures of (military) stature over the course of their history ${ }^{69}$. That same story would at the same time, however, convey both an intimation of hope and a warning to fellow Jews, still smarting from their recent first-hand exposure to Rome's military might: the same God who at the "moment" fixed by him (see 7.77a) had brought about David's overthrow of the Philistine forces could do the same with respect to the Jews' current arch-enemy, the Romans. Until that divinely determined and disclosed moment arrived, however, they, like David before them, should continue waiting, rather than attempting - as they had done recently with such disastrous results - to take the initiative against the enemy into their own hands ${ }^{70}$.

Within the vast expanse of Ant's twenty component books, the seven paragraphs of a single book treated here constitute, of course, only the 
proverbial "drop in the bucket". Still, I hope that this essay would have make clear that even so short a passage does repay the close study I have tried to give it here.

\section{NOTES:}

1 On the historical, geographical, compositional, and redaction-critical problems posed by 2 Sam 5:17-25 see, in addition to the commentaries: $C$ H Hauer, "Jerusalem, the Stronghold and Rephaim", CBQ 32(1970) 571-578; N L Tidwell, "The Philistine Incursions into the Valley of Rephaim (2 Sam v 17ff)", in J A Emerton (ed), Studies in the Historical Books of the Old Testament, Leiden $1979,190-212$.

2 On the motivation for/effect of this shift, see I Kalimi, "Literary-Chronological Proximity in Chronicles", VT 43(1993) 318-338, 320-323.

3 For the text and translation of Josephus' writings I use H St J Thackeray R Marcus A Wigren \& L H Feldman, Josephus, Cambridge, MA/London 19261965 (Ant 7.71-77 appears in Volume V, 396-401, edited by Marcus). I have likewise consulted the text and apparatus of Ant 7.71-77 in B Niese, Flavii losephi Opera, II, Berlin 21955, 104-106.

On Josephus' overall treatment of the protagonist of Ant 7.71-77, see L H Feldman, "Josephus' Portrait of David", HUCA 60(1989) 129-174.

4 According to the indications given by E C Ulrich, The Qumran Text of Samuel and Josephus, Chico, CA 1978, 271 the important, non-MT, Hebrew MS 4QSam does not contain any portion of 2 Samuel 5:17-25.

5 For B I use A E Brooke N Maclean \& H St J Thackeray (eds), The Old Testament in Greek according to the Text of Codex Vaticanus, 11:1, I and II Samuel, Cambridge 1927; idem, II:III, I and II Chronicles, Cambridge 1932.

6 For L I use N Fernández Marcos \& J R Busto Saiz (eds), El Texto Antioqueno de la Biblia Griega, I, 1-2 Samuel, Madrid 1989; idem, III, 1-2 Crónicas, Madrid 1996. Closely related to the $L$ readings in 2 Sam 5:17-25 are those given in the (fragmentary) Vetus Latina marginal notes of various medieval Spanish Vulgate MSS; for these I use C Morano Rodríguez, Glosas marginales de Vetus Latina en las Biblias Vulgatas Españolas, 1-2 Samuel, Madrid 1989, 37.

7 For the text of the Vulg. I use Biblia Sacra, V, Samuhel, Rome 1943; VIII, Verba Dierum, Rome 1948.

8 For TJ I use the text of A Sperber (ed), The Bible in Aramaic, II, Leiden 1959 and the translation of this by D J Harrington \& A J Saldarini, Targum Jonathan of the Former Prophets, Wilmington, DE 1987.

9 For TC I use the text of R le Déaut \& J Robert, Targum des Chroniques, II, Rome 1971 and the translation of this by J S McIvor, The Targum of Chronicles, Collegeville, MN 1994.

10 His motivation for doing this could that whereas 5,17b/14:8 speak of David's taking a preliminary initiative on his own volition in response to the Philistine advance ( $\mathrm{i}$ e are "going down to the stronghold", 5:17 vs "going out against them", 14:8), in what follows Josephus' emphasis will be on David's never 
acting until he had consulted God as to what he should do, see 7.72. (On the controverted question of the identity of "the stronghold" spoken of in 5:17b [Zion?, Adullam (2 Sam 23:13)?], see the commentaries and the works cited in n. 1.)

In his positioning of the account of David's two Philistine victories in 7.71-77, Josephus, it might be noted here, follows the sequence of 2 Samuel against that of 1 Chronicles, see above. In particular he situates that account directly following his parallel (7.61-70) to 2 Sam 5:6-16, a sequence featuring various achievements and acquisitions by David (capture of Jerusalem, his building a palace there, and the sons born to him in his new capital).

11 This is Josephus' standard term for the "Philistines" as opposed to that favored by LXX, i e ' $\alpha \lambda \lambda \sigma \phi v \lambda \alpha$. See R de Vaux, "Les Philistins dans la Septante", in J Schreiner (ed), Wort, Lied, Gottesspruch. Beitrdge zur Septuaginta, Würzburg $1972,185-192$.

12 In 5:17/14:8 the reference is to the Philistines' hearing that David had been

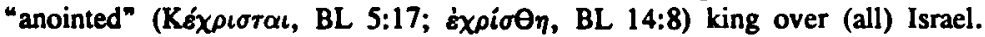
Josephus' avoidance of the sources' term may be due to the fact that in his own earlier account of the recognition of David's rule by the northern tribes in 7.53 to which his formulation here in 7.71 is alluding back, he, in contrast to his Biblical Vorlagen, i e 2 Samuel 5:3/1 Chronicles 11:3, does not mention their "anointing" him as such.

132 Samuel 5:17/1 Chronicles 14:8 leave unspecifted the identity of those who "anoint" David (in this essay I italicize items of Josephus' presentation like the above which have no parallel in the sources as such). On the historian's use of the term "Hebrews" to designate his people at various points of their history, see G Harvey, The True Israel: Uses of the Names Jew, Hebrew and Israel in Ancient Jewish and Early Christian Literature, Leiden 1996, 124-129.

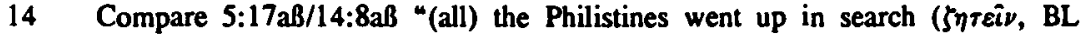
$5: 17, \zeta \eta r^{\prime} \sigma a l$, BL 14:8) of David".

15 Neither of Josephus' sources mentions "Jerusalem" as such; Josephus' specification of it as the Philistines' objective in their coming against David has in view the preceding context of his presentation, 7.61-70 (/2 Sam 5:6-16) which features precisely David's conquest of and presence in the city.

16 The codices SP read Tırá $\nu \omega \nu$ here; see $\mathrm{n} 19$.

17 Such "distance indications" are frequently inserted by Josephus into his retelling of Biblical history; they serve to underscore his personal knowledge of the regions being cited. In our pericope another such indication occurs in 7.77 , see below.

18 Note in 7.71 Josephus' double use of the historic present form (orpareviououv...

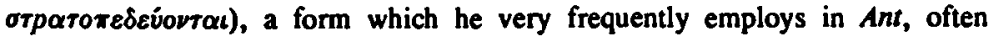
doing so where the LXX parallel has some past form. See C T Begg, Josephus' Account of the Early Divided Monarchy (AJ 8,212-420), Leuven 1993, 10-11, n. 32.

19 The above sequence "when they had taken... they encamped there" represents Josephus' version of 5:18 ("Now the Philistines had come and spread out in the valley of Rephaim", MT= RSV)/14:9 ("Now the Philistines had come and made a raid in the valley of Rephaim", MT= RSV). Josephus' use of the 
phrase $r \dot{\eta} \nu \kappa o \lambda \lambda \dot{\alpha} \delta \alpha T \hat{\omega} \nu \Gamma \iota \gamma \alpha \dot{\alpha} \nu \omega \nu$ in his rendition closely corresponds to the $\dot{\varepsilon} \nu$ $\tau \hat{\theta} \kappa \alpha \lambda \lambda \dot{\alpha} \delta t \tau \hat{\omega} \nu \gamma t \gamma \dot{\alpha} \nu \tau \omega \nu$ of BL 14:9. Compare the alternative wording of BL

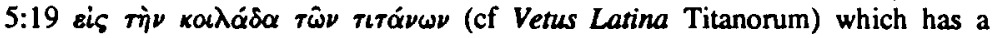
counterpart in the reading of codices SP as cited in $n 16$.

20 Compare the designation "Hebrews" in 7.71; on Josephus' use of the term "Jews" in reference to his people, see Harvey, True Israel, 47-61. Josephus' other uses of the title "king of (the) Jews" are in Bellum Judaicum (hereafter B) 6.103 (Jehoiachin), 439 (David); 7.71 (Alexander Janneus); Ant 14.9 (Herod), 36 (Alexander Janneus); 15.373 (Herod), 409 (Herod); 16.291 (Herod), 311 (Herod).

21 Josephus' other uses of the term iryuviris are in $B J$ 1.460; Ant $6.21 ; 14.81 ; 15.132$. Only here in 7.72 , however, is the term used as a designation for God.

22 In light of what precedes readers will readily identify this nameless figure with the priest Abiathar who joins David during the latter's flight from Saul (Ant 6.269/1 Sam 22:20) and who, already previously, had obtained oracles for the king, see 6.359 (/1 Sam 30:7). (In the Bible Abiathar is designated simply as "priest"; Josephus' referring to him as "high priest" here accords with the theory set forth by him in Ant 5.361-362, cf 8.12 according to which at the time of Eli, ancestor of Abiathar and himself a descendant of Aaron's younger son Ithamar, the high priesthood passed from the line of Aaron's older son Eleazar to that of Ithamar, where it remained until Solomon dismissed Abiathar as high priest and installed Eleazar's descendant Zadok in his place.)

23 Josephus' extended preface to the Biblical "inquiry notices" above underscores the king's piety, this in accord with an overall tendency of his retelling of the Scriptural accounts of David, see Feldman, "David", 156-164.

24 Such recasting of Biblical direct discourse is very frequent in Ant; see Begg, Josephus' Account, 12-13, n 38.

25 Compare the sources where David begins by asking "shall I...?".

26 This same phrase recurs in Ant 5.120; 9.190.

27 This hendiadys occurs also in Ant 4.16; 5.159; 6.25,115; 7.250.

28 On these tendencies, see L H Feldman, "Prophets and Prophecy in Josephus", JTS 41(1990) 386-422, especially 389-391, 419-421. See also n 50 on 7.76 .

29 Note the historic present; see $n .18$.

30 As Marcus, Josephus, V, 398, n. a points out, in 2 Samuel 5 it is, rather, in connection with the latter, second battle account that one hears of David's being told to come at the Philistines from the rear (see v 23). Also elsewhere in 7.7177 we will find evidence of Josephus" "scrambling" the data of the sources' two battle narratives.

31 The above embellishment of the source battle reports serves to highlight the military stature and success of David, this in line with an overall tendency of Josephus' retelling of the Biblical David story, see Feldman, "David", 141-147. See also n. 34.

32 On the various questions surrounding "Baal-perazim"- its meaning, location, prior history, versional renderings, etcetera - see the commentaries.

33 His doing so is understandable given the site's insignificance for the wider course of Israel's history and is further reflective of Josephus' general tendency 
to "streamline" in the case of the minor place and personal names cited in his Biblical sources.

34 This concern goes together with his interest in accentuating the military stature of King David, on which see n. 31. The "misconception" which Josephus' comment in 7.74 is designed to preclude is, it might be remarked, one that his own previous presentation with its elaboration of the sources' battle notices in terms of the speed and ease of David's victory might well engender on the part of readers- this necessitating precisely the editorial intervention undertaken by Josephus at this point.

35 This formulation refers back to 7.73 where, in his elaboration of the sources' battle accounts, Josephus states "at first encounter he (David) fell suddenly upon the enemy' rear, slew part of them and put the rest to flight".

36 This collocation occurs only here in Josephus.

37 Josephus' other uses of the noun $\beta \rho \alpha \delta v i \eta j s$ are in $B J 1.21 ; 6.4 ; A n t 13.47$; 18.314 .

38 Josephus' one other use of the noun $\dot{\alpha} \gamma \varepsilon \dot{v} \nu \varepsilon\llcorner\alpha$ is in $B J 1.357$; note the wordplay

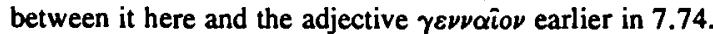

39 Josephus' other uses of this adjectival collocation are in Ant 3.42 (reverse order); $4.10 ; 5.370 ; 6.68$.

40 The sources give no indication that the Philistines had any allies in their initial advance against Israel. Josephus' mention of such allies here accordingly underscores both the magnitude of the threat facing David and the extent of his triumph in repulsing it. As for the specific nations mentioned by him as the Philistines' confederates, "all Syria" might be seen as an anticipation of the accounts of David's campaigns against that region in what follows, see 2 Samuel 8:3-8 (cf the preceding notice of David's defeat of the Philistines in $8: 1)$; 10:6-19. His reference to "Phoenicia" as also part of the Philistine coalition is more difficult to explain, all the more so since in what immediately precedes Josephus (7.66) has made use of the notice of 2 Samuel 5:11 about the aid provided David by Hiram, the king of Tyre. Perhaps, however, the mention of "Phoenicia" alongside "Syria" here is simply a more or less "mechanical" reflex of what is a frequent geographical pairing elsewhere in Josephus, see, e g, Ant 9.283; 10.220;11.21, 22, 25, 27, 60, 89, 101, 129, 138, 167.

41 For the reverse process in which Josephus "anticipates" rather than, as here, delays, a source item, see $n 30$.

42 This allusion to the Philistines' multiple defeats and the extent of their casualties has no Biblical basis. It serves to underscore the efficacy of the Hebrew fighting machine and of its leader David in the face of so tenacious a foe. See $n 44$.

$43 \quad$ Note the historic present; see $\mathbf{n} 18$.

44 Here again (see n. 42) Josephus insists that it was not just once, but repeatedly that the Israelites under David had defeated the Philistines. That the latter, nonetheless, persist in their attacks points up both their tenacity and the full significance of Israel's triumphs over them.

45 This specification of the previous reference to the Philistines' "larger force" is Josephus' embellishment of 5:22/14:13 which give no indication that the second Philistine assault involved more troops than had the first. 
With the entire above sequence compare the summary notices of 5:22 "and the Philistines came up again, and spread out in the valley of Rephaim"/14:13 "And the Philistines yet again made a raid in the valley".

47 Note that within the brief compass of 7.71-77 Josephus employs no less than three synonymous designations for David's people, i e "Hebrews" $(7.71,74,75)$, "Jews" (7.72), and "Israelites" here in 7.76.

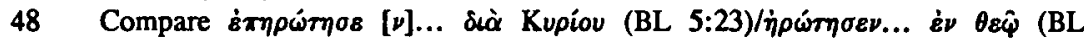

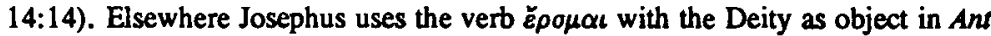
$4.87 ; 7.7 ; 8.401 ; 10.124$ (here with the preposition $\pi \alpha \rho \alpha$ ). On the historian's virtually total avoidance of the divine title "Lord" (LXX Kúpios) of 5:23 given its non-currency in secular Greek, see Begg, Josephus' Account, 45, n 218.

49 With the above phrase Josephus supplies a content- absent in 5:23// 14:14- for David's "inquiry". The phrase is reminiscent of the wording of the earlier royal inquiry in 7.72 (David directed the high priest to foretell)... what the outcome

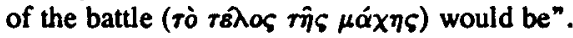

50 Note the historic present (see $n$ 18). Here again - see n. 49 - Josephus employs language reminiscent of his earlier inquiry scene, compare 7.72-73 “he (David) ordered the high priest... and when he (the high priest) prophesied

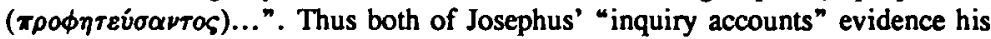
tendency to interject prophetic terminology into contexts where the Bible lacks it and to link the priesthood with the exercise of prophecy, see n. 28. By contrast, 5:23/14:14 represent the Deity as responding directly to David's "inquiry" apart from any prophetic mediation.

51 MT 5:23-24// 14:14-15 speak of כָכִָָ (RSV “balsam trees"). BL refer in 5:23 to "the weeping" ( $\tau \pi \hat{v} \kappa \lambda \alpha \nu \theta \mu \hat{\omega} \nu \circ \varsigma$ ) as the site near which David is to hold him-

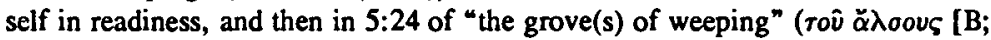
L $\tau \hat{\omega} \nu \dot{\alpha} \lambda \sigma \hat{\omega} \nu]$ rỗ $\kappa \lambda \alpha \nu \theta \mu \hat{\omega} \nu \circ \varsigma$ ), cf Vetus Latina 5:24 ("de silva in ploratu"), apparently connecting the Hebrew term used in 5:23-24// 14:14-15 with the verb בכה ("to weep"). BL 14:14-15, by contrast, make mention of "pear trees" ( $\tau \hat{\omega} \nu \nu \alpha \dot{\alpha} i \omega \nu$ ), as does the Vulgate of both Samuel and Chronicles ("pirorum"), while TJ and TC allude in more general terms to "trees" (איניניא). On these readings and the relation among them, see the commentaries.

52 The phrase "wind blowing" recurs in Ant 10.207. With the above wording of the instructions given David compare those cited in 5:23-24 (MT= RSV): “You shall not go up (BL + to meet them); go around to their rear (BL withdraw from them) and come upon them opposite the balsam trees (BL near the weeping). And when you hear the sound of marching (BL a clashing together) in the tops of the balsam trees (BL from the grove[s] of weeping) then bestir yourself (B go down to them/ L go down to the enemy) for then the Lord (TJ the angel of the Lord) has gone out before you (TJ to prosper before you) to smite the army [or camp] (BL in the battle) of the Philistines" and 14:14-15 (MT= RSV) "you shall not go up after them; go around (BL withdraw from them) and come upon them opposite the balsam trees (BL near the pear trees). And when you hear the sound of marching (B shaking together, L shaking) in the tops of the balsam trees (BL [in] the tops of the pear trees), then go out to battle, for God (TC an angel who has been sent from before the Lord) has gone out before you (TC to give success before you) to smite the army [or camp] of the Philistines". 
Note that Josephus leaves aside the statement about God's direct role in the upcoming battle with which both Biblical sequences conclude $(5: 24 b / 14: 15 b$ compare TJ and TC's substitution of a reference to the intervention of an "angel of the Lord"). On the historian's overall - though by no means invariable tendency to "de-theologize" the Biblical account in his retelling of this in Ant, see L H Feldman, "Use, Authority, and Exegesis of Mikra in the Writings of Josephus", in M J Mulder \& H Sysling (eds), Mikra: Text, Translation, Reading and Interpretation of the Hebrew Bible in Ancient Judaism and Early Christianity, Assen 1988, 455-518, 503-507. Conversely, his specification underscoring the extraordinary character of the happening in question - that the "agitation" of the grove is to occur "with no wind blowing" has no counterpart in the Biblical witnesses.

53 Elsewhere Josephus uses the verb xposixov with God as subject also in Ant 3.38; 5.18; 6.39, (49), 328; 7.96, 337; 8.11, 52, 299; 9.39. Compare 7.72

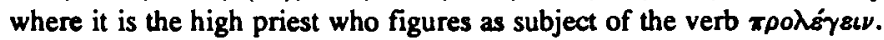

54 The entire above sequence serves to underscore the realization of God's previous prediction as well as the obedience - he waits to act until precisely the announced moment has occurred - and confident advance of David once it has. Josephus' accentuation of David's obedience here has a counterpart in Rabbinic tradition (see Pesiq Rab 8.6; Midr Pss 27.2) which describes David, in accord with the directive given him in 5:24/14:15, refraining from moving against the Philistines until the very last moment when they are practically on top of him and his men. The above passages further contrast David who acts thus with Saul who abruptly terminated his consultation of the Lord out of fear of the advancing Philistines, see 1 Samủè 14:19.

552 Samuel 5:25/14:16 do not recount the actual combat moment of the second battle incident, see above. Josephus' notice here fulls this lacuna, emphasizing the energy and speedy efficacy of David's assault on the Philistines.

56 Note the historic present (see n. 18). Compare the aorist form $\dot{\varepsilon} \pi \dot{\alpha} \tau \alpha \xi \varepsilon(\nu)$ of BL 5:25b/14:16b.

57 Compare the plusses of MT and B 5:25 made in connection with the mention of Gezer, i e "unto the entrance of Gezer" (MT $=\mathrm{TJ}, \mathrm{Vulg}) /$ "unto the land ( $\bar{\eta} \hat{\eta} \varsigma$ $\gamma \hat{\eta} \varsigma)$ of Gazara" (B).

58 With this interjected "distance indication" compare that made in 7.71 concerning the "Valley of the Giants", $i$ e "this is a place not far from the city (Jerusalem)". Here in 7.77 the interjection serves to highlight the extent of David's triumph: he drives the Philistines who had earlier advanced to a point "not far from" his capital right back to the border of their land.

59 Note the historic present (see n. 18).

60 In making explicit mention of the Philistine "camp" here, Josephus goes together with 14:16b, "they smote (so MT; BL [i் $\dot{\alpha} \tau \alpha \xi e$, like Josephus, makes David the subject) the camp (BL $\tau \dot{\eta} \nu \pi \alpha \rho e \mu \beta \circ \lambda \dot{\eta} \nu)$ of the Philistines" against 5:25b which simply has David "smiting the Philistines".

61 This indication concerning what David found in the Philistine camp is Josephus' elaboration of the "camp notice" of 14:16b (see previous note). Also elsewhere, Josephus expatiates on the valuables obtained by the Israelites from their defeated foes, doing so with a view, it would seem, of counteracting con- 
temporary claims about Jewish impecuniousness. On the point, see Feldman, “David", 138-139; Begg, Josephus' Account, 122, n. 765; idem, “Amaziah of Judah according to Josephus (Ant 9.186-204)”, Antonianum 70(1995) 3-30, 12 and n. 37.

62 In situating the item only after the second, final battle, as he does, Josephus gives it a more climactic character. Thereby too, he disposes of a question which might have suggested itself to readers of the Biblical accounts, i.e. would the Philistines really have ventured against Israel a second time after having suffered the loss of their "gods" in the first engagement?

63 Compare L 5:25b which reads like a conflation of the divergent indications of Samuel and Chronicles (see above): "and the Philistines left their gods there and David and his men took them (so MT B 5:25) and David said "burn them in fire' (so 14:12b)". On the reason for the difference between the two Biblical accounts regarding David's handling of the Philistine gods/idols, see the commentaries (which generally view the Chronicler's formulation as an attempt to bring David's initiative into line with the prescriptions of Deut 7:5,25, i e that the graven images of the inhabitants of the land are to be "burnt with fire").

64 His reason for omitting the notice may be its seemingly premature character at this juncture where, in both the Biblical and his own presentation, David still has many battles to fight against a variety of peoples, see 2 Sam 8:1-14/1 Chronicles 18:1-12/Ant 7.96-109; 2 Samuel 10:1-19/1 Chronicles 19:1-19/Ant 7.117-129.

65 On this passage of Ant see C T Begg, “David's Transfer of the Ark according to Josephus”, Bulletin for Biblical Research 7(1997) 1-26.

66 This finding for 7.71-77 is in line with the more general conclusion of $\mathbf{E} \mathbf{C}$ Ulrich, "Josephus' Biblical Text for the Books of Samuel", in L H Feldman \& G Hata (eds), Josephus, the Bible and History, Detroit 1989, 81-96 concerning the text of Samuel employed by Josephus overall.

67 This omission exemplifies the interconnectedness of Josephus' rewriting techniques in 7.71-77 in that it goes together with a large-scale "substitution" by him, see below.

68 On Ant's double target audience, see Feldman, "Mikra", 470-471.

69 On this claim and Josephus' efforts to combat it in his writings, see Feldman, "Mikra", 490-491.

70 Many other passages of Ant lend themselves to a "anti-Roman" reading as well. On the subject, see, e g, L H Feldman, "Josephus' Portrait of Daniel", Henoch 14(1992) 37-96, 66-71; C T Begg, "Josephus and Nahum Revisited", REJ 154(1995) 5-22, 19-22. 